\title{
Effects of Smartphone Addiction Prevention Program on Smartphone Addiction Tendency and Self-Control of Children using Local Children's Centers
}

\author{
Kim Minkyeong
}

\begin{abstract}
The current research takes those children using local children's centers as subjects of research, and aims to identify the effect of preventive education programs for smartphone addiction on their addiction and self-control. SPSS version 22.0 for Windows was used for data analysis to develop kinder teacher treatment play therapy for kindergarten children. Among nonparametric statistical methods, the Mann-Whitney $U$ Test and the Wilcoxon Singed-Rank Test were conducted. The results of this study are summarized as follows. The analysis of the subjects' smartphone addiction found that the educational program did produce a significant difference. Second, it was also found in the examination of the preventive educational program on the subjects' self-control that a significant increase was obtained in all the 6 factors of thoughtfulness, task tolerance, resistance against temptations, emotional control, friend-related control and teacher-related control. This study shows that it is expected that further researches would follow with a group of lower-class elementary students and ordinary children to come a more generalized conclusion.
\end{abstract}

Keywords: Smartphone Addiction Tendency, Self-Control, Local Children's Center

\section{INTRODUCTION}

L ocal children's centers basically provide children with a variety of programs in such areas as education, culture, protection, and emotional support. Often, some of the programs are customized for them by taking the characteristics of local communities and local residents[1] .

It is also true that most of the after-school programs in the centers are limited to tutoring, meals(dinner), computer classes, literacy skills, learning guidance for Chinese characters and fine arts[2]. Concerns, thus, about the necessity for a wider variety of welfare programs have been raised to keep up with children's personal and social changes [3].

Media addiction is one of the hot topics in the field. A set of media including internet, games and smartphones, often referred to as 'the other parents', now exert an enormous amount of influence on child development[4]. To take an example, a portion of potential risk group in terms of the use of smartphones was reportedly $10.7 \%$ for those in early

Revised Manuscript Received on July 22, 2019

Minkyeong Kim, Child Welfare, Namseoul University, Cheonan South Korea, ilu35@hanmail.net childhood, which is a $6 \%$ increase from the previous year[5]. What makes us concerned and troubled might be that this figure is greater than that for adults. It seems clear that voices of concern about children's addiction to smartphones should now be taken more seriously.

In general, children's addition to smartphones is closely related with low self-respect and self-control, and high depression and impulsiveness[6,7]. Many children using local children's centers, due to problems resulting from financial difficulty, are more likely to be present-focused and impulsive, and, thus, to experience depression, helplessness and negative self-image[8]. It was also reported that poor living conditions and low family bond would lead to low self-respect of those children using local children's centers and, as a consequence, to higher risk of smartphone addiction[9].

In sum, such environmental characteristics of children using local children's centers call for more attention from society than other ordinary children, and education programs should be provided to prevent them from turning into risk group of smartphone addiction and to train them to use smartphones with discernment [10]. Attempts have been made to develop and carry out such preventive programs for ordinary children, but few programs have targeted children using community children's centers.

The current research, thus, takes those children using local children's centers as subjects of research, and aims to identify the effect of preventive education programs for smartphone addiction on their addiction and self-control.

\section{METHODS}

\section{A. Research Participants}

The present research started with purposive sampling of a group of subjects, who are in the 4th to 6th grade using local children's centers located in the cities of Asan and Cheonan in Choongnam Province. We identified a group of 24 children as belonging to potential risk group (42-44 points). The subjects were classified into an experimental group of 12 children and a control group of another 12 children. The educational program lasted for 8 weeks between Oct. 10, 2018 and Dec. 1, 2018. 


\section{Effects of Smartphone Addiction Prevention Program on Smartphone Addiction Tendency and Self-Control of Children using Local Children's Centers}

\section{B. Research Tools}

Adolescents' addiction to smartphones adopted the self-evaluation scale developed by [5] to measure smartphone addiction. The tool, mainly used for teenagers, consisted of 15 items in 4 categories: 5 items for problems in daily life, 2 items for virtual world-oriented, 4 items for abstinence syndrome, and 4 items for task tolerance. Each item was measured on a 4-point Likert scale. Cronbach awas obtained at .896 .

Scale for self-control adopted [11] self-control scale developed to measure self-control of pre-schoolers. The scale consists of a total of 43 measurement items in 6 categories: 12 items for thoughtfulness, 9 patience for tasks, 7 for resistance against temptation, 6 for emotional control, 4 friend-related control and 5 for teacher-related control. The items were measured on a 5-point Likert scale. Cronbach awas obtained at .903 .

\section{Data Analysis}

The collected data was analyzed by using the statistical program of SPSS 22.0 version. A nonparametric statistical method of Mann-Whitney U test was used in order to test the homogeneity of demographic characteristics of the two groups under investigation and to validate the effectiveness of the preventive educational program. Wilcoxon Signed Rank Test, in turn, identified the differences between the pre- and post-test of smartphone addiction and self-control of the experimental and control groups.

\section{RESULTS}

\section{A. Test of Homogeneity}

Wilcoxsen signed rank test is more powerful than sign test when paired two group's difference verification.

$$
Z=\frac{T-\frac{N \mid N+1]}{4}}{\sqrt{\frac{N(N+1)[N+1}{N-1}}}
$$

Mann-Whitney U test is used because of simplification of test.

$$
\begin{aligned}
& \mathrm{U}_{1}+\mathrm{U}_{2}=\mathrm{n}_{1} \mathrm{n}_{2}+\mathrm{n}_{1} \mathrm{n}_{2}+\frac{\mathrm{n}_{1}\left(\mathrm{n}_{1}+1\right)}{2}+\frac{\mathrm{n}_{2}\left(\mathrm{n}_{2}+1\right)}{2}-\left(2^{\mathrm{R}_{1}}+\Sigma^{\mathrm{R} 2}\right) \\
& \mathrm{n}_{1} \mathrm{n}_{2}+\frac{\mathrm{n}_{1}\left(\mathrm{n}_{1}+1\right)}{2}+\frac{\mathrm{n}_{2\left(\mathrm{n}_{2}+1\right)}}{2}=\Sigma^{\mathrm{R}_{1}}+\Sigma^{\mathrm{R} 2}=1
\end{aligned}
$$

so,

$\mathrm{U}_{1}+\mathrm{U}_{2}=\mathrm{n}_{1} \mathrm{n}_{2}$

Table 1: Inter-group homogeneity in smartphone addiction and self-control

\begin{tabular}{llcccccc}
\hline & & \multicolumn{1}{c}{ average rank-su } & Mann- & & \\
& group & $\mathrm{N}$ & $\mathrm{rank}$ & $\mathrm{m}$ & Whitney U & $\mathrm{z}$ & $\mathrm{p}$ \\
\hline \hline $\begin{array}{c}\text { smartphone } \\
\text { addiction }\end{array}$ & $\begin{array}{l}\text { Experi } \\
\text { mental }\end{array}$ & 12 & 13.04 & 156.50 & 65.500 & -.382 & .703 \\
\hline
\end{tabular}

\begin{tabular}{llllllll}
\hline \hline Control & 12 & 11.96 & 143.50 & & \\
\hline \multirow{3}{*}{ self-control } & $\begin{array}{l}\text { Experi } \\
\text { mental }\end{array}$ & 12 & 11.21 & 134.50 & & & \\
\cline { 2 - 5 } & Control & 12 & 13.79 & 165.50 & & & \\
\hline
\end{tabular}

The average ranks of the experimental and the control groups were 13.04 and 11.96 , respectively, which indicates that no significant difference was found between the two groups as shown in Table 1. What it means would be that addiction to smartphones was found at a similar level and that, as a consequence, inter-group homogeneity was identified.

In a similar vein, statically significant difference was not found in terms of self-control between the two groups, which also means that inter-group homogeneity was identified before the program went into effect.

\section{B. Effect of the preventive program on reduction of the children's addiction to smartphones}

The differences in smartphone addiction of the experimental group between before and after the intervention of the program as shown in Table 2.

Table 2: Differences in smartphone addiction between

\begin{tabular}{|c|c|c|c|c|c|c|}
\hline $\begin{array}{l}\text { Exp. } \\
\text { Group(N=12) }\end{array}$ & & $\mathrm{N}$ & $\begin{array}{c}\text { average } \\
\text { rank }\end{array}$ & $\begin{array}{l}\text { rank } \\
\text { total }\end{array}$ & $\mathrm{z}$ & $\mathrm{p}$ \\
\hline \multirow{2}{*}{$\begin{array}{l}\text { smartphone } \\
\text { addiction }\end{array}$} & $\begin{array}{l}\text { negative } \\
\text { rank }^{\mathrm{a}}\end{array}$ & 12 & 6.50 & 78.00 & \multirow{4}{*}{$-3.062 * *$} & .002 \\
\hline & $\begin{array}{l}\text { positive } \\
\text { rank }^{b}\end{array}$ & 0 & .00 & .00 & & \\
\hline \multirow{2}{*}{$\begin{array}{l}\text { posttest - } \\
\text { pretest }\end{array}$} & equal $^{c}$ & 0 & & & & \\
\hline & total & 12 & & & & \\
\hline \multirow{4}{*}{$\begin{array}{l}\text { problems } \\
\text { daily life } \\
\text { posttest - } \\
\text { pretest }\end{array}$} & $\begin{array}{l}\text { negative } \\
\text { rank }^{a}\end{array}$ & 12 & 6.50 & 78.00 & \multirow{4}{*}{$-3.070 * *$} & .002 \\
\hline & $\begin{array}{l}\text { positive } \\
\text { rank }^{\mathrm{b}}\end{array}$ & 0 & .00 & .00 & & \\
\hline & equal $^{c}$ & 0 & & & & \\
\hline & total & 12 & & & & \\
\hline \multirow{2}{*}{$\begin{array}{l}\text { virtual } \\
\text { world-oriente } \\
\text { dness }\end{array}$} & $\begin{array}{l}\text { negative } \\
\operatorname{rank}^{\mathrm{a}}\end{array}$ & 8 & 5.38 & 43.00 & \multirow{4}{*}{$-2.448 *$} & .014 \\
\hline & $\begin{array}{l}\text { positive } \\
\text { rank }^{\mathrm{b}}\end{array}$ & 1 & 2.00 & 2.00 & & \\
\hline \multirow{2}{*}{$\begin{array}{l}\text { posttest - } \\
\text { pretest }\end{array}$} & equal $^{\mathrm{c}}$ & 3 & & & & \\
\hline & total & 12 & & & & \\
\hline \multirow{4}{*}{$\begin{array}{l}\text { abstinence } \\
\text { syndrome } \\
\text { posttest - } \\
\text { pretest }\end{array}$} & $\begin{array}{l}\text { negative } \\
\text { rank }^{\mathrm{a}}\end{array}$ & 11 & 6.00 & 66.00 & \multirow{4}{*}{$-2.956^{* *}$} & .003 \\
\hline & $\begin{array}{l}\text { positive } \\
\text { rank }^{\mathrm{b}}\end{array}$ & 0 & .00 & .00 & & \\
\hline & equal $^{c}$ & 1 & & & & \\
\hline & total & 12 & & & & \\
\hline \multirow{4}{*}{ task tolerance } & $\begin{array}{l}\text { negative } \\
\operatorname{rank}^{\mathrm{a}}\end{array}$ & 12 & 6.50 & 78.00 & \multirow{4}{*}{$-3.072 * *$} & .002 \\
\hline & $\begin{array}{l}\text { positive } \\
\text { rank }^{\mathrm{b}}\end{array}$ & 0 & .00 & .00 & & \\
\hline & equal $^{c}$ & 0 & & & & \\
\hline & total & 12 & & & & \\
\hline
\end{tabular}
before and after the intervention of the program for the experimental group

posttest=pretest 
The results of the analysis of the differences in smartphone addiction of the experimental group found 12 cases of minus signs and no positive sign. The average rank, when the result in the posttest was smaller than that in the pretest, was obtained at 6.50 , and it was 0.00 when larger. The contrast was statistically significant at the level of $p<.01$. Thus, it can be assumed that the preventive education program exerted a positive influence and helped reduce their addiction. Here, a negative number indicates that smartphone addiction in the posttest was less than that in the pretest. Moreover, the differences in smartphone addiction between the posttest and the pretest were not insignificant for the control group. This clearly supports the conclusion that the education program was effective in reducing the subjects' smartphone addiction.

\section{Effect of the preventive education program on self-control of the subjects}

Wilcoxson Signed Rank Test intended to examine the differences in self-control ability between the pre- and post-test obtained the following results shown in Table 3.

Table 3: Differences in self-control between before and after the intervention of the program for the experimental group

\begin{tabular}{|c|c|c|c|c|c|c|}
\hline $\begin{array}{l}\text { Experimental } \\
(\mathrm{N}=12)\end{array}$ & & $\mathrm{N}$ & $\begin{array}{c}\text { average } \\
\text { rank }\end{array}$ & $\begin{array}{c}\text { rank-su } \\
\mathrm{m}\end{array}$ & $\mathrm{Z}$ & $\mathrm{p}$ \\
\hline \multirow{4}{*}{$\begin{array}{l}\text { self-control } \\
\text { posttest - } \\
\text { pretest }\end{array}$} & $\begin{array}{l}\text { negative } \\
\text { rank }^{a}\end{array}$ & 0 & .00 & .00 & \multirow{4}{*}{$\begin{array}{c}-3.065^{*} \\
*\end{array}$} & \multirow{4}{*}{.002} \\
\hline & $\begin{array}{l}\text { positive } \\
\text { rank }^{\text {b }}\end{array}$ & 12 & 6.50 & 78.00 & & \\
\hline & equal $^{c}$ & 0 & & & & \\
\hline & total & 12 & & & & \\
\hline \multirow{4}{*}{ thoughtfulness } & $\begin{array}{l}\text { negative } \\
\operatorname{rank}^{a}\end{array}$ & 0 & .00 & .00 & \multirow{4}{*}{$\begin{array}{c}-3.069 * \\
*\end{array}$} & \multirow{4}{*}{.002} \\
\hline & $\begin{array}{l}\text { positive } \\
\text { rank }^{b}\end{array}$ & 12 & 6.50 & 78.00 & & \\
\hline & equal $^{c}$ & 0 & & & & \\
\hline & total & 12 & & & & \\
\hline \multirow{4}{*}{ task tolerance } & $\begin{array}{l}\text { negative } \\
\operatorname{rank}^{a}\end{array}$ & 0 & .00 & .00 & \multirow{4}{*}{$\begin{array}{c}-3.074 * \\
*\end{array}$} & \multirow{4}{*}{.002} \\
\hline & $\begin{array}{l}\text { positive } \\
\text { rank }^{b}\end{array}$ & 12 & 6.50 & 78.00 & & \\
\hline & equal $^{\mathrm{c}}$ & 0 & & & & \\
\hline & total & 12 & & & & \\
\hline \multirow{2}{*}{$\begin{array}{l}\text { resistance } \\
\text { against } \\
\text { temptations }\end{array}$} & $\begin{array}{l}\text { negative } \\
\operatorname{rank}^{a}\end{array}$ & 0 & .00 & .00 & \multirow{4}{*}{$\begin{array}{c}-3.069 * \\
*\end{array}$} & \multirow{4}{*}{.002} \\
\hline & $\begin{array}{l}\text { positive } \\
\text { rank }^{b}\end{array}$ & 12 & 6.50 & 78.00 & & \\
\hline \multirow{2}{*}{$\begin{array}{l}\text { posttest - } \\
\text { pretest }\end{array}$} & equal $^{c}$ & 0 & & & & \\
\hline & total & 12 & & & & \\
\hline \multirow{4}{*}{$\begin{array}{l}\text { emotional } \\
\text { control }\end{array}$} & $\begin{array}{l}\text { negative } \\
\text { rank }^{\mathrm{a}}\end{array}$ & 0 & .00 & .00 & \multirow{4}{*}{$\begin{array}{c}-3.062 * \\
*\end{array}$} & \multirow{4}{*}{.002} \\
\hline & $\begin{array}{l}\text { positive } \\
\text { rank }^{b}\end{array}$ & 12 & 6.50 & 78.00 & & \\
\hline & equal $^{\mathrm{c}}$ & 0 & & & & \\
\hline & total & 12 & & & & \\
\hline
\end{tabular}

\begin{tabular}{|c|c|c|c|c|c|c|}
\hline \multirow{4}{*}{$\begin{array}{l}\text { friend-related } \\
\text { control } \\
\text { posttest - } \\
\text { pretest }\end{array}$} & $\begin{array}{l}\text { negative } \\
\text { rank }^{\mathrm{a}}\end{array}$ & 0 & .00 & .00 & \multirow{4}{*}{$\begin{array}{c}-3.070^{*} \\
*\end{array}$} & \multirow{4}{*}{.002} \\
\hline & $\begin{array}{l}\text { positive } \\
\text { rank }^{\mathrm{b}}\end{array}$ & 12 & 6.50 & 78.00 & & \\
\hline & equal $^{c}$ & 0 & & & & \\
\hline & total & 12 & & & & \\
\hline \multirow{4}{*}{$\begin{array}{l}\text { teacher-related } \\
\text { control }\end{array}$} & $\begin{array}{l}\text { negative } \\
\text { rank }^{\mathrm{a}}\end{array}$ & 0 & .00 & .00 & \multirow{4}{*}{$\begin{array}{c}-3.074 * \\
*\end{array}$} & \multirow{4}{*}{.002} \\
\hline & $\begin{array}{l}\text { positive } \\
\text { rank }^{\mathrm{b}}\end{array}$ & 12 & 6.50 & 78.00 & & \\
\hline & equal $^{c}$ & 0 & & & & \\
\hline & total & 12 & & & & \\
\hline
\end{tabular}

** $\mathrm{p}<.01$ a. posttest<pretest, $b$. posttest $>$ pretest, c. posttest=pretest

All the 12 cases marked positive (+) values. The average rank was 0.00 when the data in the posttest was smaller than that in the pretest, while it was 6.50 when larger. The difference was found statistically significant at the level of $\mathrm{p}<$. 01 as shown in Table 3. Again, therefore, it can be concluded that the preventive education program was effective in helping enhancing the subjects' self-control. Here, the result in a positive sign indicates that the subjects' self-control was higher in the posttest than in the pretest.

The control group, on the other hand, did not show statistically significant difference between the post- and the pretest, which also supports our conclusion that the preventive education program would help enhance the self-control of the children under discussion.

\section{DISCUSSIONS AND CONCLUSION}

First, the analysis of the subjects' smartphone addiction found that the educational program did produce a significant difference, as expected, in all the factors of problems in daily life, abstinence syndrome, tolerance and virtual world-oriented. Significant changes in daily life problems and tolerance, which may well be related with self-regulation ability and impulsiveness, could result from letting them go through the stage of increasing self-control. It might be assumed that explanation of the side effects and adverse effects of overuse of smartphones aroused their attention and led to such positive changes.

Second, it was also found in the examination of the preventive educational program on the subjects' self-control that a significant increase was obtained in all the 6 factors of thoughtfulness, task tolerance, resistance against temptations, emotional control, friend-related control and teacher-related control. Such a result might indicate that a greater level of seeking long-term satisfaction would lead to a lower level of smartphone addiction.

In other words, a higher level of self-control can be closely related with a higher level of resistance against temptations and impulsiveness, which would eventually lead to planning and controlling the use of smartphones. 


\section{Effects of Smartphone Addiction Prevention Program on Smartphone Addiction Tendency and Self-Control of Children using Local Children's Centers}

To conclude, the present research found that the preventive education program would help the children under discussion improve their self-control, better face a variety of other possible problems at home or school than smartphone addiction and grow as responsible members of society with desirable character.

Based on the findings of the research, a few suggestions for future researches are worthwhile to note. A small size of samples and regional limitation make it hard to come to a generalized conclusion. The post-test was conducted right at the conclusion of the educational program. That is, we have not identified long lasting results and effect of such programs. Moreover, a variety of other factors including depression, stress, school life, and/or parenting behavior must be taken into consideration in future researches. Finally, it is expected that further researches would follow with a group of lower-class elementary students and ordinary children to come a more generalized conclusion.

\section{ACKNOWLEDGMENT}

Funding for this paper was provided by Namseoul University

\section{REFERENCES}

1. R. D. Conger, J. A. McCarty, R. K. Yang, B. B. Lahey, J. P. Kropp, "Perception of child, child-rearing values, and emotional distress as mediating links between environmental stressors and observed maternal behavior" Child development, 2234-2247, 1984.

2. M. R. Gottfredson, T. Hirschi, A general theory of crime: Stanford University Press, 1990.

3. M. J. Shanahan, A. Davey, J. Brooks, "Dynamic models of poverty and psychosocial adjustment through childhood" Journal of Human Resources, 36, 500-519, 1998.

4. N. J. Salkind, C. F. Nelson, "A note on the developmental nature of reflection-impulsivity" Developmental psychology, 16(3), 237-238, 1980.

5. K. T. Oh, J. E. Lee, "Samart life revolution and smartphone addiction" Internet and Information Security, 3(4), 21-43, 2012.

6. P. C. Kendall, L. E. Wilcox, "Self-control in children: Development of a rating scale" Journal of consulting and clinical psychology, 47(6), 1020-1029, 1979.

7. National Information Association. Development of smartphone addiction, 1997.

8. C. B. Kopp, "Antecedents of self-regulation: A developmental perspective” Developmental psychology, 18(2), 199-214, 1982.

9. Mischel HN, Mischel W. "The development of children's knowledge of self-control strategies" Child development. 1983; 603-619.

10. D. L. Newman, A. Caspi, T. E. MoffittTE, P. A. Silva, “Antecedents of adult interpersonal functioning: Effects of individual differences in age 3 temperament" Developmental psychology, 33(2), 206-217, 1997.

11. G. R. Patterson, "Performance models for antisocial boys" American psychologist. 41(4), 432-444, 1986.

\section{AUTHORS PROFILE}

Kim, Minkyeong professor, dept. of child welfare, Namseoul University, Masters degree of Ewha Womans University, PhD. Catholic University of Korea. director of Association of Child \& Family Counseling. She concerns about mental health, multicultural family, adolescents 